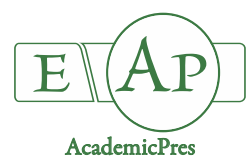

\title{
Influence of Selected Antibiotics on the Tomato Regeneration in In Vitro Cultures
}

\author{
Aneta GERSZBERG ${ }^{1 *}$, Izabela GRZEGORCZYK-KAROLAK ${ }^{2}$ \\ ${ }^{1}$ University of Lodz, Faculty of Biology and Environmental Protection, Department of Molecular Biotechnology and Genetics, 90-237 Lodz, \\ Banacha 12/16, Poland; aneta.gerszberg@biol.uni.lodz.pl ("correspondingauthor) \\ ${ }^{2}$ Medical University of Lodz, Department of Biology and Pharmaceutical Botany, 90-151 Lodz, Muszyńskiego 1, \\ Poland; izabela.grzegorczyk@umed.lodz.pl
}

\begin{abstract}
Generally, antimicrobial agents are frequently used in micropropagation techniques to obtain free elite clones or after genetic transformation to select putative transformants. Their successful application minimizes bacterial contamination however; they may be phytotoxic and may diversely affect the regeneration ability in plant tissue cultures. The objective of the current study was to estimate the effects of four antibiotics i.e. ampicillin, carbenicillin, cefotaxime and kanamycin on morphogenesis of three Polish tomato cultivars, cultured on MS medium with phytohormones. In this experiment the ability of tomato cotyledon explants to regenerate entire plants via indirect organogenesis was tested. Among four antibiotics tested, kanamycin was most harmful for the explants. This antibiotic, even at low doses $(10-20 \mathrm{mg} / \mathrm{L})$, inhibited tomato morphogenesis. On the other hand, the current study revealed significant influence of different concentrations of ampicillin, carbenicillin, cefotaxime on the frequency of bud formation. While the addition of cefotaxime at low concentration (100-200 $\mathrm{mg} / \mathrm{L}$ ) stimulated the bud formation, its increasing concentration adversely affected the organogenesis of tomato. The results clearly pointed out that carbenicillin and ampicillin at low concentrations $(100-400 \mathrm{mg} / \mathrm{L})$ were not only non-toxic, but they promoted bud regeneration. The obtained results show the crucial role not only of use of efficient antibiotics, but also of their proper doses in obtaining successful transformation and regeneration of tomato.
\end{abstract}

Keywords: aminoglycosides; $\beta$-lactam antibiotics; Solanum lycopersicum; tissue culture Abbreviations: AMP: ampicillin; BAP-6: benzylaminopurine; CARB: carbenicillin;CEF: cefotaxime; IAA: indole-3-acetic acid; KM: kanamycin; MS: Murashige and Skoog medium; PAA: phenylacetic acid

\section{Introduction}

Efficient regeneration protocol is a crucial for successful genetic manipulation aiming at plant improvement. Techniques routinely used (agroinfection) to introduce foreign genes into a plant genome require the application of specific antibiotics (e.g. selectable or germicidal ones) (Kazemi et al., 2014; Sun et al., 2015). The vulnerability of plant tissue to antibiotics depends on a broad range of factors including species, genotype, explant type, culture conditions, so it is indispensable to verify the impact of given antibiotics on plant tissue, before the transformation procedure (Mamidala and Swamy Nanna, 2009; Farzaneh et al., 2013; Gerszberg et al., 2015b; Sun et al., 2015).

Antibiotics belonging to the $\beta$-lactam antibiotic group (e.g. ampicillin, carbenicillin, cefotaxime) and aminoglycosides (e.g. kanamycin) are most frequently exploited in plant transformation research (Kazemi et al., 2014; Sun et al., 2015). However, these antimicrobial agents can be not only toxic but they may also influence the regeneration response of a plant tissue (Sharma et al., 2012; Kazemi et al., 2014; Mahadev et al., 2014). Some literature data pointed out that antibiotics positively affected explant growth and/or shoot and root differentiation (Grzebelus and Skop, 2014; Meng et al., 2014). This phenomenon could be explained by the auxin-related structure of the $\beta$ lactam antibiotics which allows them to imitate the action of plant hormones (Grewal et al., 2006; Mahadev et al., 2014). This large class of antibiotics, which is chemically heterologous, is known to be active against both Grampositive and Gram-negative bacteria. The influence of $\beta$ lactam antibiotics on in vitro cultures of different plant species (eg. Oryza sativa, hybrid aspens, Centella asiatica (L.), Daucus carota, Brassica rapa ssp.pekinensis (L.), Tectona 
grandis (L.)) (Grewal et al., 2006; Bosela, 2009; Grzebelus and Skop, 2014; Meng et al., 2014; Panathula et al., 2014; Tambarussi et al., 2015) Cucumis melo (L.) was investigated.

To the best of our knowledge, there is little information on the impact some of the aforementioned antibiotics on the tomato regeneration (Sharma et al., 2012). Moreover, most of the research considered only antibiotics at a low concentration range. Thus, the current study focused on the influence of the selected antibiotics used at a wide range of concentrations on organogenesis of different tomato cultivars.

\section{Materials and Methods}

\section{Plant material}

In the present study three commercially available cultivars ('Jokato', 'Frodo' and 'Poranek') of tomato (Solanum lycopersicum L.) were used. The chosen cultivars are popular and widely cultivated in Poland. The seeds purchased from PlantiCo Ltd. (Zielonki, Poland) were surface sterilized with $70 \%(\mathrm{v} / \mathrm{v})$ ethanol for 2 minutes and next treated with $15 \%$ commercial bleach for 10 minutes. Subsequently, they were rinsed 4 times in sterile distilled water. The sterilized seeds were placed on $1 / 2$ MS medium ( $1 \%$ sucrose, $0.8 \%$ agar, $\mathrm{pH}=5.8$ ) (Murashige and Skoog, 1962) and cultured for 10 days.

\section{Origin of explants and culture conditions}

In the present investigation, cotyledons were tested as explants because they gave better morphogenic response in comparison to hypocotyls as it was described in our previous work (Gerszberg et al., 2016). Explants originating from cotyledons excised in a sterile way from 10-day-old seedlings and placed on MS basal medium (3\% sucrose, $0.8 \%$ agar, $\mathrm{pH}=5.8$ ) supplemented with BAP (6-benzylaminopurine $(2 \mathrm{mg} / \mathrm{L})$ and IAA (indole-3-acetic acid) $(0.2 \mathrm{mg} / \mathrm{L})$ as well as on MS medium with the aforementioned phytohormones and the tested antibiotics, ampicillin (AMP), carbenicillin (CARB), cefotaxime (CEF) (each of them in concentrations: $100,200,300,400,500,600,800$, $1000 \mathrm{mg} / \mathrm{L})$ and kanamycin (KM) (0, 10, 20, 30, 40, 50 $\mathrm{mg} / \mathrm{L})$. The $\mathrm{pH}$ of all media was adjusted before autoclaving. The antibiotics as well as IAA were appended after the media were autoclaved when their temperature was approximately $55-60{ }^{\circ} \mathrm{C}$. The cultures were placed under controlled conditions: at $23^{\circ} \mathrm{C}$ under a $16 / 8 \mathrm{~h}$ (light/dark) photoperiod regime (3000 lux, approx.).

\section{Data analysis}

The data were recorded every four weeks while the regeneration characteristics were collected on a continuous basis. Each variant of treatment was performed in three replications. For one replication (in the case of KM) 72 explants (12 cotyledons per each variant of medium), were used. In the case of CEF, CARB and AMP - for one replication 108 explants were used. The frequency of shoot regeneration was evaluated for cotyledons that had been cultured for 30 days, as described in our previous work (Gerszberg et al., 2015b; Gerszberg et al., 2016).
Statistical analysis

All the values in this study were expressed as mean \pm standard error (SE). The statistical analysis was performed with Statistica 10.0 software (Statsoft Poland) for repeated measurements. The statistically significant differences were also assessed by applying the Kruscal-Wallis test $(\mathrm{p}<0.05)$.

\section{Results}

\section{Control variants}

In the control variants (explants grown on MS media +2 $\mathrm{mg} / \mathrm{L} \mathrm{BAP}+0.2 \mathrm{mg} / \mathrm{L} \mathrm{IAA}$ ) callus induction was observed on the surface of all three tomato cultivars tested. The explants began swelling after 3-4-day culture and callus initiation started after 10-12 days at the cut edges. The visible callus was cream-yellow and green. Shortly thereafter bud formation on the obtained callus tissue was observed. Among the tested cultivars slight differences in bud frequency formation were recorded; the shoot regeneration efficiency varied from $92 \%$ for variety 'Poranek' to $94 \%$ for 'Frodo' (Tables 1-3) (no statistical differences between cultivars). The explants formed on average 1.4 to 1.8 buds, depending on the variety.

\section{Influence of ampicillin on shoot regeneration and callus} induction

Ampicillin added to MS medium with PGRs, regardless of its concentration, triggered callus formation in all cultivars (86\%-100\%) (no statistical differences between varieties). Moreover, the presence of ampicillin in the medium contributed to the accelerated formation of buds. They began to appear after 12-14 days compared to $~ 16$ days for the control. However, the high rate of callus formation at all ampicillin concentrations used did not translate into an equally high ability to regenerate the shoots. For all three varieties, after treatment with the lowest ampicillin concentration $(100 \mathrm{mg} / \mathrm{L})$ shoot formation dynamics and the number of obtained shoots were similar to the control (Tables 1-3). With increasing concentration of this antibiotic gradual decrease in these parameters was observed. And at its highest concentration $(1000 \mathrm{mg} / \mathrm{L})$, organogenesis was found only on about $50 \%$ of explants (Tables 1-3).

\section{Influence of carbenicillin on shoot regeneration and callus induction}

Similarly to ampicillin, in case of carbenicillin frequency of callus formation was very high. Among three tested cultivars callus induction ranged from $92 \%$ to $100 \%$ and only slight differences in callus initiation connected with antibiotic concentration was found (for cultivar 'Poranek' and 'Jokato', no statistical difference between various carbenicillin content were found) (Tables 1-3). Moreover, carbenicillin supplementation positively influenced the process of bud formation, which began to appear after 1314 days in comparison to $\sim 16$ days for the control variants. At these antibiotic concentrations from $100 \mathrm{mg} / \mathrm{L}$ to 400 $\mathrm{mg} / \mathrm{L}$, the organogenesis efficiency for all varieties was similar to that obtained in the control (no statistical 
560

differences). For 'Frodo' and 'Jokato' varieties, the numbers of shoots obtained under these conditions were also similar to those in the controls. Only in the case of 'Poranek' cultivar, even slightly increasing concentration of carbenicillin (up to $200 \mathrm{mg} / \mathrm{L}$ ) resulted in a decrease in the number of buds obtained. Further increase in the antibiotic concentration caused gradual decrease in bud formation frequency. The lowest efficiency (about 50\%) was observed in the presence of $1000 \mathrm{mg} / \mathrm{L}$ carbenicillin, it was twice lower than in the (medium without antibiotic).

Influence of cefotaxime on shoot regeneration and callus induction

In contrast to these two abovementioned antibiotics, the concentration of cefotaxime in the medium influenced the percentage of callus formation. This was particularly evident in the case of 'Poranek' variety, where the induction of callus tissue fluctuated in the range of $49.6-100 \%$. However, the observed differences between treatments were usually not statistically significant due to a large discrepancy between the results within one concentration (Tables 1-3). Additionally, supplementation of culture media with cefotaxime contributed to delaying callus formation by 2-3 days with respect to the control, and on the media with cefotaxime at the concentrations above $400 \mathrm{mg} / \mathrm{L}$ the callus culture began to brown with time. The highest response in bud regeneration frequency was observed at the lowest concentrations of this antibiotic (100-200 mg/L). However, the observed percentage of regeneration (60$70 \%$ ) (depending on the cultivar) was significantly lower in the presence of cefotaxime compared to the control. Regardless of the variety, the increasing concentration of cefotaxime caused significant decrease in bud differentiation; starting from $600 \mathrm{mg} / \mathrm{L}$, no buds were noticed on the explants (Tables 1-3).

\section{Influence of kanamycin on shoot regeneration and callus} induction

The addition of kanamycin had an adverse effect on the formation and differentiation of the callus tissue on tomato explants (Tables 1-3). In all media supplemented with the antibiotic, callus initiation was delayed by about 3 days, in comparison with the control. This antibiotic only at its two (for 'Poranek' and 'Jokato') or three (for 'Frodo') lowest

Table 1. The effect of different concentration of antibiotics on Solanum lycopersicum cv. 'Frodo', regeneration

\begin{tabular}{|c|c|c|c|}
\hline $\begin{array}{l}\text { Type and concentration of the } \\
\text { antibiotics }[\mathrm{mg} / \mathrm{L}]\end{array}$ & $\begin{array}{c}\text { Percentage of explants capable to } \\
\text { organogenesis }\end{array}$ & $\begin{array}{c}\text { Mean } \\
\text { No. of buds per explants }\end{array}$ & $\begin{array}{c}\text { Callus induction } \\
(\%)\end{array}$ \\
\hline Control & $94.17 \pm 1.78 \mathrm{ab}$ & $1.63 \pm 0.065 \mathrm{ab}$ & $99.31 \pm 0.69 \mathrm{ab}$ \\
\hline AMP 100 & $94.44 \pm 5.56 a b$ & $1.41 \pm 0.087 b c$ & $91.67 \pm 4.82 \mathrm{bc}$ \\
\hline AMP 200 & $86.11 \pm 2.78 b$ & $1.35 \pm 0.089 \mathrm{bc}$ & $97.22 \pm 2.78 \mathrm{ab}$ \\
\hline AMP 300 & $91.67 \pm 4.82 \mathrm{ab}$ & $1.12 \pm 0.059 \mathrm{~cd}$ & $97.22 \pm 2.78 \mathrm{ab}$ \\
\hline AMP 400 & $91.67 \pm 4.82 \mathrm{ab}$ & $1.15 \pm 0.064 \mathrm{~cd}$ & $100 \pm 0.0 \mathrm{a}$ \\
\hline AMP 500 & $80.55 \pm 2.78 b$ & $1.17 \pm 0.073 c d$ & $97.22 \pm 2.78 \mathrm{ab}$ \\
\hline AMP 600 & $77.78 \pm 10.03 \mathrm{bcd}$ & $1.14 \pm 0.069 \mathrm{~cd}$ & $94.45 \pm 2.78 \mathrm{abc}$ \\
\hline AMP 800 & $66.66 \pm 12.74 \mathrm{~cd}$ & $1.17 \pm 0.079 \mathrm{~cd}$ & $94.45 \pm 2.78 \mathrm{abc}$ \\
\hline AMP 1000 & $55.56 \pm 7.36 \mathrm{~d}$ & $1.25 \pm 0.102 b c d$ & $97.22 \pm 2.78 \mathrm{ab}$ \\
\hline CARB 100 & $88.89 \pm 2.78 b$ & $1.59 \pm 0.15 \mathrm{abc}$ & $100 \pm 0.0 \mathrm{a}$ \\
\hline CARB 200 & $94.44 \pm 5.56 \mathrm{ab}$ & $1.50 \pm 0.14 a b c$ & $97.22 \pm 2.78 \mathrm{ab}$ \\
\hline CARB 300 & $97.22 \pm 2.78 a$ & $1.20 \pm 0.08 \mathrm{bc}$ & $94.44 \pm 5.56 \mathrm{abc}$ \\
\hline CARB 400 & $94.45 \pm 2.78 \mathrm{ab}$ & $1.44 \pm 0.12 \mathrm{abc}$ & $91.67 \pm 4.82 \mathrm{bc}$ \\
\hline CARB 500 & $86.11 \pm 2.78 b$ & $1.03 \pm 0.033 \mathrm{~cd}$ & $91.67 \pm 0.0 \mathrm{c}$ \\
\hline CARB 600 & $83.33 \pm 4.82 b$ & $1.00 \pm 0.0 \mathrm{~d}$ & $97.22 \pm 2.78 \mathrm{ab}$ \\
\hline CARB 800 & $63.89 \pm 2.78 \mathrm{~cd}$ & $1.09 \pm 0.061 \mathrm{~cd}$ & $94.44 \pm 5.56 \mathrm{abc}$ \\
\hline CARB 1000 & $55.55 \pm 2.78 d$ & $1.05 \pm 0.051 \mathrm{~cd}$ & $94.45 \pm 2.78 \mathrm{abc}$ \\
\hline CEF 100 & $66.67 \pm 12.74 c d$ & $1.75 \pm 0.19 \mathrm{ab}$ & $100 \pm 0.0 \mathrm{a}$ \\
\hline CEF 200 & $66.67 \pm 4.82 \mathrm{~cd}$ & $1.54 \pm 0.16 \mathrm{ab}$ & $97.22 \pm 2.78 \mathrm{ab}$ \\
\hline CEF 300 & $50.0 \pm 14.45 \mathrm{~d}$ & $1.83 \pm 0.19 \mathrm{ab}$ & $91.67 \pm 4.82 \mathrm{bc}$ \\
\hline CEF 400 & $30.55 \pm 2.78 \mathrm{e}$ & $1.36 \pm 0.15 b c$ & $91.67 \pm 4.82 \mathrm{bc}$ \\
\hline CEF 500 & $25.0 \pm 4.82 \mathrm{e}$ & $1.11 \pm 0.11 \mathrm{~cd}$ & $94.45 \pm 2.78 \mathrm{abc}$ \\
\hline CEF 600 & $0.0 \pm 0.0$ & $0.0 \pm 0.0$ & $91.67 \pm 4.82 \mathrm{bc}$ \\
\hline CEF 800 & $0.0 \pm 0.0$ & $0.0 \pm 0.0$ & $83.33 \pm 4.82 c$ \\
\hline CEF 1000 & $0.0 \pm 0.0$ & $0.0 \pm 0.0$ & $83.3 \pm 4.82 c$ \\
\hline KM 10 & $52.78 \pm 2.78 \mathrm{~d}$ & $1.47 \pm 0.14 \mathrm{abc}$ & $88.89 \pm 7.36 \mathrm{bc}$ \\
\hline KM 20 & $19.45 \pm 2.78 \mathrm{e}$ & $1.29 \pm 0.18 \mathrm{bcd}$ & $61.11 \pm 10.03 d$ \\
\hline KM 30 & $2.78 \pm 2.78 f$ & $2.00 \pm 0.0 \mathrm{a}$ & $11.11 \pm 2.78 \mathrm{e}$ \\
\hline KM 40 & $0.0 \pm 0.0$ & $0.0 \pm 0.0$ & $5.55 \pm 2.78 \mathrm{e}$ \\
\hline KM 50 & $0.0 \pm 0.0$ & $0.0 \pm 0.0$ & $0.0 \pm 0.0$ \\
\hline
\end{tabular}

Results are the mean of three determinations \pm SE. The means marked with the same letter do not differ significantly according to the Kruskal-Wallis, at $5 \%$ significance level 
Table 2. The effect of different concentration of antibiotics on Solanum lycopersicum cv. 'Jokato', regeneration

\begin{tabular}{|c|c|c|c|}
\hline $\begin{array}{c}\text { Type and concentration of the } \\
\text { antibiotics }[\mathrm{mg} / \mathrm{L}]\end{array}$ & $\begin{array}{c}\text { Percentage of explants capable to } \\
\text { organogenesis }\end{array}$ & $\begin{array}{c}\text { Mean } \\
\text { No. of buds per explants }\end{array}$ & $\begin{array}{c}\text { Callus induction } \\
(\%)\end{array}$ \\
\hline Control & $93.06 \pm 2.72 \mathrm{ab}$ & $1.75 \pm 0.07 a$ & $98.61 \pm 1.39 a$ \\
\hline AMP 100 & $88.89 \pm 5.56 a b c$ & $1.78 \pm 0.16 a$ & $91.67 \pm 4.82 \mathrm{ab}$ \\
\hline AMP 200 & $91.67 \pm 4.82 \mathrm{ab}$ & $1.36 \pm 0.086 \mathrm{ab}$ & $91.67 \pm 4.82 \mathrm{ab}$ \\
\hline AMP 300 & $88.89 \pm 5.56 \mathrm{abc}$ & $1.32 \pm 0.087 \mathrm{ab}$ & $97.22 \pm 2.78 \mathrm{a}$ \\
\hline AMP 400 & $83.33 \pm 9.63 \mathrm{abc}$ & $1.17 \pm 0.07 \mathrm{~b}$ & $94.44 \pm 5.56 \mathrm{ab}$ \\
\hline AMP 500 & $75.0 \pm 4.82 \mathrm{bcd}$ & $1.11 \pm 0.063 \mathrm{~b}$ & $94.44 \pm 5.56 \mathrm{ab}$ \\
\hline AMP 600 & $69.0 \pm 5.56 \mathrm{bcd}$ & $1.12 \pm 0.068 b$ & $100.0 \pm 0.0 \mathrm{a}$ \\
\hline AMP 800 & $55.55 \pm 14.71 \mathrm{cdef}$ & $1.25 \pm 0.102 b$ & $97.22 \pm 2.78 \mathrm{a}$ \\
\hline AMP 1000 & $52.78 \pm 15.48 \mathrm{cdef}$ & $1.21 \pm 0.099 \mathrm{~b}$ & $91.67 \pm 4.82 \mathrm{ab}$ \\
\hline CARB 100 & $88.89 \pm 5.56 \mathrm{abc}$ & $1.91 \pm 0.16 \mathrm{a}$ & $97.22 \pm 2.78 \mathrm{a}$ \\
\hline CARB 200 & $97.22 \pm 2.78 a$ & $1.66 \pm 0.13 \mathrm{ab}$ & $100.0 \pm 0.0 \mathrm{a}$ \\
\hline CARB 300 & $91.67 \pm 8.34 \mathrm{abc}$ & $1.64 \pm 0.13 \mathrm{ab}$ & $94.44 \pm 5.56 \mathrm{ab}$ \\
\hline CARB 400 & $86.11 \pm 2.78 b c$ & $1.52 \pm 0.11 \mathrm{ab}$ & $94.45 \pm 2.78 \mathrm{ab}$ \\
\hline CARB 500 & $69.44 \pm 5.56 \mathrm{bcd}$ & $1.52 \pm 0.10 \mathrm{ab}$ & $97.22 \pm 2.78 \mathrm{a}$ \\
\hline CARB 600 & $55.56 \pm 7.35 \mathrm{de}$ & $1.4 \pm 0.11 \mathrm{ab}$ & $91.67 \pm 4.82 \mathrm{ab}$ \\
\hline CARB 800 & $52.78 \pm 16.92 \mathrm{cdef}$ & $1.21 \pm 0.099 \mathrm{~b}$ & $91.67 \pm 4.82 \mathrm{ab}$ \\
\hline CARB 1000 & $52.78 \pm 10.03 \mathrm{cdef}$ & $1.15 \pm 0.088 b$ & $94.44 \pm 5.56 \mathrm{ab}$ \\
\hline CEF 100 & $72.22 \pm 2.78 \mathrm{~d}$ & $1.52 \pm 0.02 \mathrm{ab}$ & $94.44 \pm 5.56 \mathrm{ab}$ \\
\hline CEF 200 & $61.11 \pm 5.56 \mathrm{de}$ & $1.59 \pm 0.17 \mathrm{ab}$ & $83.33 \pm 9.63 a b c$ \\
\hline CEF 300 & $44.44 \pm 7.36 \mathrm{ef}$ & $1.69 \pm 0.20 \mathrm{ab}$ & $72.22 \pm 12.12 b c$ \\
\hline CEF 400 & $27.78 \pm 5.56 f$ & $1.2 \pm 0.14 b$ & $72.22 \pm 7.36 \mathrm{bc}$ \\
\hline CEF 500 & $16.67 \pm 0.0 \mathrm{~g}$ & $1.0 \pm 0.0 \mathrm{~b}$ & $72.22 \pm 10.03 b c$ \\
\hline CEF 600 & $0.0 \pm 0.0$ & $0.0 \pm 0.0$ & $72.22 \pm 7.36 b c$ \\
\hline CEF 800 & $0.0 \pm 0.0$ & $0.0 \pm 0.0$ & $69.45 \pm 14.72 \mathrm{bcd}$ \\
\hline CEF1000 & $0.0 \pm 0.0$ & $0.0 \pm 0.0$ & $66.67 \pm 17.47 \mathrm{abcd}$ \\
\hline KM 10 & $50.0 \pm 4.82 \mathrm{e}$ & $1.39 \pm 0.17 \mathrm{ab}$ & $100.0 \pm 0 \mathrm{a}$ \\
\hline KM 20 & $38.89 \pm 2.78 \mathrm{ef}$ & $1.29 \pm 0.13 \mathrm{ab}$ & $55.55 \pm 2.78 c$ \\
\hline KM 30 & $0.0 \pm 0.0$ & $0.0 \pm 0.0$ & $50.0 \pm 8.34 \mathrm{~cd}$ \\
\hline KM 40 & $0.0 \pm 0.0$ & $0.0 \pm 0.0$ & $38.89 \pm 2.78 \mathrm{~d}$ \\
\hline KM 50 & $0.0 \pm 0.0$ & $0.0 \pm 0.0$ & $0.0 \pm 0.0$ \\
\hline
\end{tabular}

concentrations triggered callus formation and organogenesis. It was the only one among the antibiotics used in our study which markedly inhibited callus formation. Prolonged treatment with high kanamycin concentrations (more than $20 \mathrm{mg} / \mathrm{L}$ ) was lethal for explants. Kanamycin at the concentration of $50 \mathrm{mg} / \mathrm{L}$ (and in the case of 'Poranek' variety even of $30 \mathrm{mg} / \mathrm{L}$ ) completely inhibited the formation of callus on explants. As it can be seen in the Tables 1-3, even the use of kanamycin at the optimal concentration $(10 \mathrm{mg} / \mathrm{L})$ decreased frequency of bud formation in comparison to the control variants. In presence of kanamycin at the concentration of $30 \mathrm{mg} / \mathrm{L}$, only $2.78 \%$ bud frequency was noticed in the case of cv. 'Frodo', while the two other cultivars did not give any morphogenic response.

The results of regeneration (\% of shoot regeneration, $\%$ of callus induction, and number of buds on explant) obtained for all cultivars were also correlated with the antibiotic type and concentration (Table 4). In all cases, very high negative correlations were observed between capability for organogenesis for all cultivars and antibiotics concentration ( $\mathrm{r}$ between -0.86 and -0.97 ); the organogenesis ability of explants decreased with the increase antibiotics concentrations. Lower correlation coefficients were found for number of buds obtained on the explants in the case of all cultivars for ampicillin, in the case of 'Poranek' cultivar for carbenicillin and in the case of 'Frodo' cultivar for kanamycin. The greatest differences connected with the type of antibiotic and the variety used, concerned the ability to form callus. For example, lack of relationships were observed between \% frequency of callus formation and ampicillin concentration for 'Frodo' and 'Jokato' cultivars (respectively, 0.1 and 0.03), while for the 'Poranek' cultivar, the percentage of callus induction was highly correlated with the ampicillin content (-0.87).

\section{Discussion}

A wide range of antibiotics is routinely used in culture media for plant tissue after genetic transformation to eliminate Agrobacterium or as a selective agent (Gerszberg, 2018). Since it was evidenced that antibiotics supplemented to culture media could have a positive or negative effect on morphogenetic processes in in vitro cultures (Grzebelus and Skop, 2014; Meng et al., 2014; Saporta et al., 2014; Naderi et al., 2016), accurate assessment of their effects on plant recovery is fully justified. Not only, must the effectiveness of an antibiotic in eliminating bacteria, but also its impact on 
562

Table 3. The effect of different concentration of antibiotics on Solanum lycopersicum cv. 'Poranek', regeneration

\begin{tabular}{|c|c|c|c|}
\hline $\begin{array}{c}\text { Type and concentration of the } \\
\text { antibiotics }[\mathrm{mg} / \mathrm{L}]\end{array}$ & $\begin{array}{c}\text { Percentage of explants capable to } \\
\text { organogenesis }\end{array}$ & $\begin{array}{c}\text { Mean } \\
\text { No. of buds per explants }\end{array}$ & $\begin{array}{c}\text { Callus induction } \\
(\%)\end{array}$ \\
\hline Control & $92.42 \pm 2.49 \mathrm{a}$ & $1.39 \pm 0.053 \mathrm{ab}$ & $97.22 \pm 1.88 \mathrm{a}$ \\
\hline AMP 100 & $88.89 \pm 2.78 \mathrm{ab}$ & $1.28 \pm 0.082 \mathrm{ab}$ & $94.44 \pm 5.56 \mathrm{ab}$ \\
\hline AMP 200 & $91.67 \pm 4.82 \mathrm{ab}$ & $1.21 \pm 0.073 b$ & $91.67 \pm 4.82 \mathrm{ab}$ \\
\hline AMP 300 & $88.89 \pm 5.56 \mathrm{ab}$ & $1.19 \pm 0.071 b c$ & $88.89 \pm 5.56 \mathrm{ab}$ \\
\hline AMP 400 & $83.33 \pm 4.82 \mathrm{~b}$ & $1.17 \pm 0.07 b c$ & $88.89 \pm 2.78 b$ \\
\hline AMP 500 & $72.30 \pm 9.98 b c$ & $1.11 \pm 0.063 \mathrm{bc}$ & $86.11 \pm 2.78 b$ \\
\hline AMP 600 & $63.89 \pm 7.36 \mathrm{~cd}$ & $1.22 \pm 0.09 b$ & $88.89 \pm 2.78 b$ \\
\hline AMP 800 & $50.0 \pm 4.82 \mathrm{~cd}$ & $1.24 \pm 0.109 \mathrm{abc}$ & $83.33 \pm 9.63 \mathrm{ab}$ \\
\hline AMP 1000 & $50.0 \pm 12.74 \mathrm{~cd}$ & $1.11 \pm 0.078 b \mathrm{c}$ & $86.11 \pm 2.78 b$ \\
\hline CARB 100 & $86.11 \pm 2.78 \mathrm{ab}$ & $1.39 \pm 0.11 \mathrm{abc}$ & $97.22 \pm 2.78 \mathrm{a}$ \\
\hline CARB 200 & $97.22 \pm 2.78 a$ & $1.09 \pm 0.049 c$ & $100 \pm 0.0 \mathrm{a}$ \\
\hline CARB 300 & $91.67 \pm 4.82 \mathrm{ab}$ & $1.06 \pm 0.043 c$ & $94.44 \pm 5.56 \mathrm{ab}$ \\
\hline CARB 400 & $83.33 \pm 9.63 \mathrm{abc}$ & $1.06 \pm 0.048 c$ & $97.22 \pm 2.78 \mathrm{a}$ \\
\hline CARB 500 & $75.0 \pm 8.34 b c$ & $1.04 \pm 0.038 c$ & $94.45 \pm 2.78 \mathrm{ab}$ \\
\hline CARB 600 & $72.22 \pm 7.36 b c$ & $1.08 \pm 0.054 c$ & $91.67 \pm 4.82 \mathrm{ab}$ \\
\hline CARB 800 & $58.33 \pm 9.63 \mathrm{~cd}$ & $1.10 \pm 0.067 \mathrm{bc}$ & $91.67 \pm 4.82 \mathrm{ab}$ \\
\hline CARB 1000 & $52.78 \pm 14.72 \mathrm{cde}$ & $1.11 \pm 0.074 \mathrm{bc}$ & $94.44 \pm 5.56 \mathrm{ab}$ \\
\hline CEF 100 & $69.44 \pm 19.47 \mathrm{bcd}$ & $1.48 \pm 0.104 a b$ & $94.44 \pm 5.56 \mathrm{ab}$ \\
\hline CEF 200 & $69.45 \pm 14.72 \mathrm{bcd}$ & $1.16 \pm 0.076 b c$ & $83.33 \pm 9.63 \mathrm{ab}$ \\
\hline CEF 300 & $41.66 \pm 8.34 \mathrm{de}$ & $1.67 \pm 0.19 \mathrm{a}$ & $72.22 \pm 12.12 b$ \\
\hline CEF 400 & $25.0 \pm 4.82 \mathrm{ef}$ & $1.22 \pm 0.156 b c$ & $49.55 \pm 22.49 \mathrm{~b}$ \\
\hline CEF 500 & $11.14 \pm 2.82 \mathrm{f}$ & $1.25 \pm 0.25 \mathrm{abc}$ & $75.0 \pm 12.74 \mathrm{~b}$ \\
\hline CEF 600 & $0.0 \pm 0.0$ & $0.0 \pm 0.0$ & $72.22 \pm 7.36 b$ \\
\hline CEF 800 & $0.0 \pm 0.0$ & $0.0 \pm 0.0$ & $69.45 \pm 14.72 b$ \\
\hline CEF1000 & $0.0 \pm 0.0$ & $0.0 \pm 0.0$ & $69.44 \pm 19.47 \mathrm{ab}$ \\
\hline KM 10 & $41.67 \pm 12.74 \mathrm{cdef}$ & $1.67 \pm 0.19 \mathrm{a}$ & $72.22 \pm 12.12 b$ \\
\hline KM 20 & $11.11 \pm 5.56 f$ & $1.0 \pm 0.0$ & $5.55 \pm 2.78 c$ \\
\hline KM 30 & $0.0 \pm 0.0$ & $0.0 \pm 0.0$ & $0.0 \pm 0.0$ \\
\hline KM 40 & $0.0 \pm 0.0$ & $0.0 \pm 0.0$ & $0.0 \pm 0.0$ \\
\hline KM 50 & $0.0 \pm 0.0$ & $0.0 \pm 0.0$ & $0.0 \pm 0.0$ \\
\hline
\end{tabular}

Results are the mean of three determinations \pm SE. The means marked with the same letter do not differ significantly according to the Kruskal-Wallis, at $5 \%$ significance level.

Table 4. Correlation coefficients $(\mathrm{r})$ between antibiotics concentrations and different regeneration parameter for three cultivars of tomato

\begin{tabular}{|c|c|c|c|c|c|}
\hline Parameter & Cultivar & AMP & CARB & CEF & KM \\
\hline \multirow{3}{*}{$\begin{array}{c}\% \text { explants capable to } \\
\text { organogenesis }\end{array}$} & 'Frodo' & -0.94 & -0.88 & -0.94 & -0.91 \\
\hline & 'Jokato' & -0.97 & -0.91 & -0.93 & -0.92 \\
\hline & 'Poranek' & -0.96 & -0.94 & -0.91 & -0.86 \\
\hline \multirow{3}{*}{ Number of buds } & 'Frodo' & -0.62 & -0.84 & -0.89 & -0.74 \\
\hline & 'Jokato' & -0.72 & -0.96 & -0.91 & -0.92 \\
\hline & 'Poranek' & -0.65 & -0.59 & -0.85 & -0.90 \\
\hline \multirow{3}{*}{$\%$ callus induction } & 'Frodo' & -0.10 & -0.53 & -0.93 & -0.96 \\
\hline & 'Jokato' & -0.03 & -0.69 & -0.85 & -0.96 \\
\hline & 'Poranek' & -0.87 & -0.69 & -0.60 & -0.86 \\
\hline
\end{tabular}

Bold- strong correlation, red- lack of correlation

plant tissues be investigated. However, establishment of an efficient plant regeneration system in the presence of antibiotics, which is the first step to obtain modified plants, is still far from routine. This study presents the report evaluating the effect of four antibiotics (ampicillin, carbenicillin, cefotaxime and kanamycin) at different concentrations on bud regeneration in tomato cultures.

Kanamycin is one of the antibiotics most commonly used as selective agents in plant transformation process (Saporta et al., 2014; Sun et al., 2015), although a wide range of species is extremely sensitive to it (Zhang et al., 2001; Sharma et al., 2012; Mahadev et al., 2014; Meng et al., 2014; Gambhir et al., 2017). Our research revealed that among the antibiotics studied, kanamycin was most harmful for the explants. Even at the lowest concentrations, it significantly reduced callus and shoot formation of all tomato cultivars in comparison to the control. The explant response was completely inhibited for all cultivars by kanamycin at the concentrations of $50 \mathrm{mg} / \mathrm{L}$. Similar results were obtained in lettuce (Ahmed et al., 2007), potato 
(Khokan et al., 2009) or grapevine (Saporta et al., 2014). It is not surprising as that kanamycin belongs to aminoglycoside antibiotics, antibacterial agents that inhibit protein biosynthesis. For this reason, it could also decrease plant growth and regeneration ability (Katayama et al., 2003).

The other antibiotics tested (except cefotaxime in the case of 'Poranek' cultivar) strongly affected explant dedifferentiation but no significant concentration-related differences concerning callus frequency formation were observed. Similar results were obtained for Chinese cabbage (Brassica rapa L. ssp. pekinensis) (Meng et al., 2014) and melon (Cucumis melo var. 'Gorgab') (Naderi et al., 2016). $\beta$ Lactams do not inhibit plant growth, because their mechanism of antibacterial activity is based on blocking the biosynthesis of peptidoglycan, one of the components of a bacterial cell wall, which is not present in plant cells (Shaikh et al., 2015). On the other hand, the present study showed significant influence of the used antibiotics and their concentration on the frequency of bud formation. This remains in line with the results of other authors showing that the presence of $\beta$-lactam antibiotics in the medium could be important for plant morphogenesis (Bosela 2009; Panathula et al., 2014; Tambarussi et al., 2015). In the present investigation, cefotaxime added to the culture medium strongly stimulated callus formation, however, its influence on tomato organogenesis was unfavourable, and with increasing concentration it inhibited bud formation frequency. Similar results were noticed in Solanum viarum ('Dunal') (Mahadev et al., 2014), Centella asiatica L. (Panathula et al., 2014) and Chinese cabbage (Meng et al., 2014). Moreover, correspondingly to our results, Meng et al. (2014) and Naing et al. (2014) showed phytotoxicity of cefotaxime, especially at high concentrations to $S$. lycopersicum explants. On the other hand, Gambhir et al. (2017) observed no significant influence of cefotaxime concentrations $(0-500 \mathrm{mg} / \mathrm{L})$ on cabbage (cv. 'Pride of India') regeneration potential. In contrast to our findings, the positive effect of cefotaxime on plant morphogenesis was shown for indica rice (Grewal et al., 2006) or melon (Naderi et al., 2016). However, Grewal et al. (2006) tested this antibiotic only at a very low concentration $(100 \mathrm{mg} / \mathrm{L})$. Additionally, Tambarussi et al. (2015) observed that cefotaxime, but also only at lower concentrations 100 and $300 \mathrm{mg} / \mathrm{L}$ stimulated morphogenesis of Tectona grandis.

In the present study, carbenicillin, which was the most useful antibiotic for Solanum lycopersicum organogenesis, revealed a double nature of action depending on its concentration. The positive effect of its lower concentrations $(100-400 \mathrm{mg} / \mathrm{L})$ on tomato morphogenesis was noticed. Similar findings were recorded by Grzebelus and Skop (2014) in carrot protoplast culture and by Mamidala and Swamy Nanna (2009) in tomato. The stimulating properties of carbenicillin, as well as of other $\beta$ lactam antibiotics, result from its chemical structure. Carbenicillin belongs to penicillin $G$ group antibiotics and is degraded to phenylacetic acid (PAA), a natural auxin (Meng et al., 2014). Several studies indicated that auxins were required to induce callus formation and morphogenesis (Wei et al., 2003; Bosela, 2009). High callus induction ability was observed in our study for all concentrations of carbenicillin, and other antibiotics of this group. However, the higher concentrations of carbenicillin (800-1000 $\mathrm{mg} / \mathrm{L})$ decreased tomato capability of organogenesis. Bosela (2009) and Tambarussi et al. (2015) connected this with carbenicillin degradation model and the fact that the excess of its auxin-derivative degradation products could inhibit plant organogenesis. According to Tambarussi et al. (2015), B-lactam antibiotics strongly induce callus formation, but at high concentrations negatively affect shoot regeneration.

In the present investigation, ampicillin semisynthetic penicillin) exerted a similar effect on tomato morphogenesis as carbenicillin. Moreover, this antibiotic, especially at lower concentrations, was beneficial for bud regeneration of all used S. lycopersicum cultivars. Similar biological activities of these two antibiotics are due to their similar benzene ringshaped structure. Our findings are coherent with Haddadi et al. (2015) results. However, Bosela (2009) and Meng et al. (2014) obtained different results concerning the morphological changes caused by these antibiotics in Populus sp. and Brassica rapa. On the other hand, it is known that the stimulatory effects of the tested $\beta$-lactam antibiotics may not only be attributed to their chemical properties which simulate plant PGRs action, but may also depend on the tested plant species and their genotypes. It could be connected with the difference in endogenous hormone levels among different species/cultivars and their different sensitivity to plant growth regulators.

\section{Conclusions}

Based on the literature data, it appears that the effect of antibiotics on regeneration largely depends on plant species and their cultivars. Moreover, kind of an antibiotic selected and its concentration are significant factors, because the presence of antibiotics in the medium could inhibit the regeneration of a plant. Our studies confirm the fact that the cultivar and the type of antibiotic as well as its concentration affect tomato regeneration. The obtained results showed that carbenicillin and ampicillin at low concentrations could be used as selection agents in $S$. lycopersicum cultures to control Agrobacterium growth. These antibiotics at the $100-400 \mathrm{mg} / \mathrm{L}$ concentrations were non-toxic to tomato cells and promoted bud regeneration. Additionally the compounds, especially carbenicillin, had a broad spectrum of activity and effectively eliminated most bacteria strains. On the other hand, the results clearly pointed to the unfavourable effect of high concentrations of ampicillin and carbenicillin on the tomato regeneration process. Therefore, determination of their right dose is crucial for future transformation and regeneration of this plant.

\section{Acknowledgements}

This research was supported by University of Lodz (research fund B1811000000201.01).

AG performed an experiment designed the outline of the article and wrote the manuscript. IG-K performed statistical analysis and was responsible for verification of the paper. All authors read and approved the manuscript. 
564

\section{References}

Ahmed MB, Akhter MS, Hossain M, Islam R, Chaudhary TA, ... Ahmed I (2007). An efficient Agrobacterium-mediated genetic transformation method of lettuce (Lactuca sativa L.) with an aphidicidal gene pta (Pinellia ternate Agglutinin). Middle East Journal of Scientific Research 2(2):155-160.

Bosela MJ (2009). Effect of $\beta$-lactam antibiotics, auxins, and cytokinins on shoot regeneration from callus cultures of two hybrid aspens, Populus tremuloides $\mathrm{x} P$. tremula and $P$. x canescens $\mathrm{x} P$. gradientata. Plant Cell Tissue and Organ Culture 98(3):249-261.

Farzaneh A, Adel Y, Ali N, Younes G (2013). Determine effective concentration of $\beta$-lactam antibiotics against three strains of Agrobacterium tumefaciens and phytotoxity on tomato and tobacco. International Journal of Agronomy and Plant Production 11(4):29192925.

Gambhir G, Kumar P, Srivastava DK (2017). Effect of antibiotic sensitivity on different cultured tissues and its significance in genetic transformation of cabbage Brassica oleracea. Bioscience Biotechnology Research Communications 10(4):652-661.

Gerszberg A (2018).Tissue culture and genetic transformation of cabbage (Brassica oleracea var.capitata): an overview.Planta 248:1037-1048.

GerszbergA, Hnatuszko-Konka K, Kowalczyk T, KononowiczAK(2016). Efficient in vitro callus induction and plant regeneration protocol for different Polish tomato cultivars. Notulae Botanicae Horti Agrobotanici Cluj-Napoca 44(2):452-458.

Gerszberg A, Hnatuszko-Konka K, Kowalczyk T (2015a). In vitro regeneration of eight cultivars of Brassica oleracea var. capitata In Vitro Cellular and Developmental Biology-Plant 51(1):80-87.

Gerszberg A, Hnatuszko-Konka K. Kowalczyk T, Kononowicz AK (2015b). Tomato (Solanum bycopersicum L.) in the service of biotechnology. Plant Cell Tissue and Organ Culture 120(3):881-902.

Grewal D, Gill R, Gosal SS (2006). Influence of antibiotic cefatoxime on somatic embryogenesis and plant regeneration in indica rice Biotechnology Journal 1(10):1158-1162.

Grzebelus E, Skop L (2014). Effect of $\beta$-lactam antibiotics on plant regeneration in carrot protoplast cultures. In Vitro Cellular and Developmental Biology-Plant 50(5):568-575.

Haddadi F, Aziz MA, Abdullah SNA, Tan SG, Kamaladini H (2015). An efficient Agrobacterium-mediated transformation of strawberry cv. Camarosa by dual plasmid system. Molecules 20(3):3647-3666.

Katayama N, Takano H, Sugiyama M, Takio S, Sakai A, ... Ono K (2003). Effects of antibiotics that inhibit the bacterial peptidogycan synthesis pathway on moss chloroplast division. Plant Cell Physiology 44(7):776781.

Kazemi EM, Jonoubi P, Majd A, Pazhouhandeh, M (2014). Reduction of negative effects of cefatoxime in tomato transformation by using FeEDDHA. International Journal of Farming and Allied Sciences 3(5):538-542

Khokan EH, Hayder A, Ara T, Alam MK, Sharma MD (2009). Enhancement of Agrobacterium-mediated transformation method for the production of heme-protein (Ferritin protein) rich potato. International Journal of Agriculture and Crop Sciences 4(2009): 17-22.
Mahadev MD, Panathila CS, Naidu CV (2014). Influence of bavistin, cefotaxime, kanamycin and silver thiosulphate on plant regeneration of Solanum viarum (Dunal)- an important anticancer medicinal plant. American Journal of Plant Science 5(3):403-408.

Mamidala P, Swamy Nanna R (2009). Influence of antibiotics on regeneration efficiency in tomato. Plant Omics 2(4):135-140.

MengQ,LiuZ,Zhang Y,Liu C, Ren F, FengH(2014).Effects of antibiotics on in vitro - cultured cotyledons. In Vitro Cellular and Developmental Biology-Plant 50(4):436-441.

Murashige T, Skoog F (1962). A revised medium for rapid growth and bioassays with tobacco tissue cultures. Physiologia Plantarum 15(3):473497.

Naderi D, Askari-Khorasgani O, Mahmoudi E (2016). Cefotaxime and benzyladenine improve melon regeneration. Iranian Journal of Biotechnology 14(1):56.

Naing AH, Park KI, Lim SH, Kim CHK (2014). Appropriate choice of antibiotics for plant regeneration and optimization of selective agents to be used in genetic transformation of chrysanthemum. Plant Omics 7(4): 237-243.

Pantahula CS, Mahadev MDN, Naidu CV (2014). The stimulatory effects of the antimicrobial agents bavistin, cefotaxime and kanamycin on in vitro plant regeneration of Centella asiatica (L.) - an important antijaundice medicinal plant. American Journal Plant Sciences 5(3):279-285.

Saporta R, De La Torre F, Segura A, Vidal JR (2014). Toxic effect of antibiotics in grapevine (Vitis vinifera 'Albariño') for embryo emergence and transgenic plant regeneration from embryogenic cell suspension.Vitis 53(2):89-94.

Shaikh S, Fatima J, Shakil S, Rizvi SMD, Kamal MA (2015). Antibiotic resistance and extended spectrum beta-lactamases: Types, epidemiology and treatment. SaudiJournal of Biological Sciences 22(1):90-101.

Sharma C, Aggarwal G, Srivastava DK (2012). Effect of antibiotic kanamycin on cultured cotyledon and hypocotyl tissues of tomato (Solanum lycopersicum cv. 'Solan vajr'). International Journal of Agriculture Environment and Biotechnology 5(2):77-82.

Sun S, XP, Xing XJ, Xu XY, Cheng J, ... Xing GM (2015).Agrobacteriummediated transformation of tomato (Lycopersicon esculentum $\mathrm{L}$. cv. 'Hezuo908') with improved efficiency. Biotechnology and Biotechnological Equipment 29(5):861-868.

Tambarussi EV, Rogalski M, Nogueira FTS, Brondani GE, De Martin VF, Carrer H (2015). Influence of antibiotics on indirect organogenesis of teak. Annals of Forest Research 58(1):177-183.

Wei T, Harris L, Newton RJ (2003). Influences of antibiotics on plantlet regeneration via organogenesis in loblolly pine (Pinus taeda L.). Journal of Forestry Research 14(3):185-190.

ZhangBH,LiuF, LiZH, WangHM, Yao CB(2001).Effects of kanamycin on tissue culture and somatic embryogenesis in cotton. Plant Growth Regulation 33(2):137-149. 